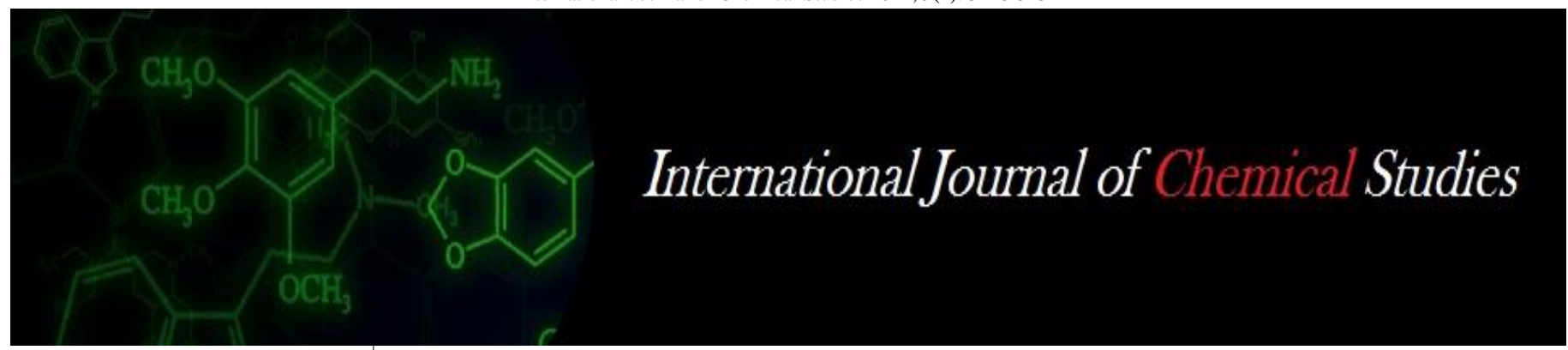

P-ISSN: 2349-8528

E-ISSN: 2321-4902

www.chemijournal.com

IJCS 2021; 9(1): 3428-3431

(C) 2021 IJCS

Received: 04-10-2020

Accepted: 16-12-2020

\section{Ashwini VN}

Department of Soil Science and Agricultural Chemistry, College of Horticulture, Bagalkote,

University of Horticultural

Sciences, Navanagar, Bagalkote,

Karnataka, India

Sanjeevraddi G Reddi

College of Horticulture, UHS,

Bagalkote, Karnataka, India

\section{Champa BV}

College of Agriculture, UAHS,

Shivamogga, Karnataka, India

\section{Nagaraja MS}

College of Agriculture, UAHS,

Shivamogga, Karnataka, India

\section{Shirol AM}

College of Horticulture, UHS,

Bagalkote, Karnataka, India

Mulla SA

College of Horticulture, KRCCH,

Arabhavi, Karnataka, India
Corresponding Author:

Ashwini VN

Department of Soil Science and Agricultural Chemistry, College

of Horticulture, Bagalkote,

University of Horticultural

Sciences, Navanagar, Bagalkote,

Karnataka, India

\section{Effect of silicic acid application on growth, flower yield and quality of gerbera cultivars under protected condition}

\author{
Ashwini VN, Sanjeevraddi G Reddi, Champa BV, Nagaraja MS, Shirol \\ AM and Mulla SA
}

DOI: $\underline{\text { https://doi.org/10.22271/chemi.2021.v9.i1av.11766 }}$

\begin{abstract}
A study on performance of gerbera cultivars for different levels of silicic acid application was carried out under protected condition. The results revealed that among all seven cultivars, 'Marinilla' recorded with higher number of flowers (15.11) and lower number of flowers observed with cultivar 'Vilassar' (13.11). Cultivars 'Vilassar' and 'Amelie' recorded with higher flower diameter $(11.88 \mathrm{~mm})$ than 'Natasha' $(10.47 \mathrm{~mm})$. Stalk length was recorded higher with cultivar 'Marinilla' $(70.16 \mathrm{~cm})$ and lower stalk length was observed in cultivar 'Nijela' $(64.16 \mathrm{~cm})$ after fourth spray. Flowers of cultivars 'Vilassar' and 'Amlet' was recorded with higher vase life (13.88 days) compared to other cultivars. Silicic acid spray showed better results with respect to number of flowers, flower diameter, stalk length and vase life of flower. Foliar spray of silicic acid $2 \mathrm{ml} / \mathrm{L}$ of water was recorded with higher vase life of flower (14.33 days). Treatment without silicic acid $(0 \mathrm{ml} / \mathrm{L})$ recorded with lower vase life $(12.76$ days $)$.
\end{abstract}

Keywords: Gerbera cultivars, silicic acid, vase life, foliar spray, 2 and $4 \mathrm{ml} / \mathrm{L}$ of water

\section{Introduction}

Silicon (Si) though not yet classed as an essential nutrient but it exists in all plants grown in soil and is considered as a functional nutrient. Silicon is the second most abundant element in the planet or earth's crust, where soils contain approximately 32 percent Si by weight (Lindsay, 2016) ${ }^{[8]}$. Most of the sources of silicon are insoluble and not in a plant available forms (Richmond and Sussman, 2003) ${ }^{[16]}$. The amounts of clay, organic matter and soil $\mathrm{pH}$ may have an influence on Si-availability similar to that of their influence on plant nutrient availability (Nagaraja and Srinivasamurthy, 2009; Reddy et al., 2012) ${ }^{[11,15]}$. Its concentration in plant dry matter ranges from $1 \%$ to $10 \%$ or higher (Gunnarson and Arnorsson, 200) ${ }^{[4]}$. The plant absorbs Si from the soil solution in the form of Mono silicic acid ( $\left.\mathrm{Si}(\mathrm{OH})_{4}\right)$. Silicon has also been offered to act as a physical barrier on leaf surfaces because of Si deposition in plant cell walls, cell lumens and trichomes and it is reasonable to expect that $\mathrm{Si}$ may strengthen plant tissues and thus creates a barrier that impedes direct penetration of fungal pathogens. Si improves flower quality of gerbera by providing mechanical strength to the flower stems since their diameter increases with increasing $\mathrm{Si}$ concentration in the nutrient solution. Accumulation of $\mathrm{Si}$ in the culms, hulls and leaves will enhance the strength and rigidity of cell walls, decreases transpiration from the cuticle and also increases resistance to lodging, low and high temperature levels, UV radiations, abiotic stresses and increases postharvest quality. It improves light interception by keeping leaves erect, thereby stimulating canopy photosynthesis in rice (Ma and Takahashi, 2002) ${ }^{[9]}$. Thicker stems are desirable for cut flowers as it allows floral designers to create more challenging floral designs that last longer. The gerbera plants amended with $\mathrm{Si}$ in the nutrient solution had significantly thicker flower stems and a higher proportion of flowers graded Class I. Taking all the above facts into consideration and the paucity of research work on silicon nutrition under protected conditions of Bagalkote, the present study on gerbera cultivars was conducted. 


\section{Material and Methods \\ Treatment details}

The study consists of 3 silicic acid levels and 7 gerbera cultivars. Silicon is supplied in the form of silicic acid as a foliar spray. 4 sprays of silicic acid are done. First spray of silicic acid was initiated during the month of August. Four foliar sprayings were carried out with the gap of one month each. The observations on growth and yield parameters were recorded at monthly intervals.

Main plot (Gerbera cultivars): C1. Rionegro (light pink), C2. Nijela (purple), C3. Marinilla (orange), C4. Natasha (red), C5.Vilassar (yellow), C6. Amlet (red), C7. Amelie (white).

Sub - plot (Silicic acid levels)-S1: No silicic acid, S2: Silicic acid at $2 \mathrm{ml} / \mathrm{L}$ of water, S3: Silicic acid at $4 \mathrm{ml} / \mathrm{L}$ of water.

\section{Source and composition of silicic acid}

Concentrated soluble silicic acid (liquid) was obtained from Department of Soil Science and Agricultural Chemistry, UAS, GKVK, Bengaluru. The material is composed of $2.0 \%$ soluble Silicic acid $\left(\mathrm{H}_{4} \mathrm{SiO}_{4}\right), \mathrm{K}$ as $\mathrm{KCl}(1.2 \%)$, B as $\mathrm{H}_{3} \mathrm{BO}_{3}$ $(0.8 \%), \mathrm{HCl}(1.0 \%)$, Demi water $(47.0 \%)$ and PEG-400 $(48.0 \%)$.

\section{Recording of observations}

Observations were recorded from five uniformly grown plants in each treatment which were tagged. The observations were assessed to find the effect of silicic acid treatments on growth parameters, development, quality and yield of gerbera cultivars. Observations were recorded after monthly sprays of silicic acid. Total four readings were recorded after each silicic acid spray. The first silicic acid foliar spray was taken during August month 2019. All the recorded observations were subjected to statistical analysis.

\section{Leaf nutrient analysis}

Table 1: Methods employed for the analysis of plant samples

\begin{tabular}{|c|c|c|c|}
\hline Sl. No. & Parameters & Methods & References \\
\hline 1 & Silicon (\%) & $\begin{array}{c}\text { Colorimetric molybdenum } \\
\text { blue method }\end{array}$ & $\begin{array}{c}\text { (Ma } \text { et al., 2002) } \\
{[9]}\end{array}$ \\
\hline
\end{tabular}

\section{Determination of Si in plant samples}

Samples collected were thoroughly washed with deionized water and oven dried at $60^{\circ} \mathrm{C}$ to obtain constant weight. Later leaf tissues were powdered for further analysis. Powdered plant sample $(0.1 \mathrm{~g})$ was pre-digested with $7 \mathrm{~mL} \mathrm{HNO}_{3}(70 \%)$, $2 \mathrm{~mL} \mathrm{H}_{2} \mathrm{O}_{2}(30 \%)$ and $1 \mathrm{~mL} \mathrm{HF} \mathrm{(40 \% )} \mathrm{in} \mathrm{PTFE} \mathrm{(Poly} \mathrm{Tetra}$
Fluoro Ethylene) tubes and later digested using a microwave digester at $150{ }^{\circ} \mathrm{C}$. The digested sample was stored in clean plastic tubes of $50 \mathrm{~mL}$ capacity, after making up the volume using 4\% boric acid solution (Ma and Takahashi 2002) [9]. Silicon in the digested plant sample was determined by the colorimetric molybdenum blue method at $600 \mathrm{~nm}$ (Ma et al. 2002; Narayanaswamy and Prakash 2009) ${ }^{[9,13]}$.

\section{Statistical analysis}

The data obtained from experimental area about all the above parameters was tabulated and analyzed statistically by adopting two factorial completely randomized design (CRD) procedures (OPSTAT software). The results were tested at $1 \%$ level of significance using Fischer's method. Critical difference was calculated whenever ' $F$ ' test was found to be significant.

\section{Results and Discussion \\ Growth parameters \\ Plant height}

After fourth spray of silicic acid, observation on plant height was significantly higher with cultivar 'Marinilla' $(39.11 \mathrm{~cm})$ over 'Vilassar' $(36.56 \mathrm{~cm})$ but was on par with other gerbera cultivars (Table 2). Plant height differed significantly with silicic acid levels at all stages of growth. After $4^{\text {th }}$ foliar spray, silicic acid application level (foliar spray) with $2 \mathrm{ml} / \mathrm{L}$ of water recorded significantly higher plant height. The improvement in root growth attributes like increase in root number, root mass, root volume and root length which might have resulted in more root biomass and improves plant height of cultivar. The variation observed here might be due to difference in genetic constituents among the cultivars along with the environmental effects. Chauhan (2005) ${ }^{[2]}$ observed similar results in an experiment conducted with gerbera.

\section{Number of leaves per plant}

The number of leaves differed significantly with silicic acid levels. Application of silicic acid levels with $2 \mathrm{ml} / \mathrm{L}$ of water recorded significantly higher number of leaves (31.04) over 0 $\mathrm{ml} / \mathrm{L}$ of water (27.38) but it was on par with foliar spray of 4 $\mathrm{ml} / \mathrm{L}$ of water (30.61). Interaction effect of gerbera cultivars and silicic acid levels on number of leaves did not differed significantly (Table 2). The increase in number of leaves per plant was a result of enhanced leaf initial breaks i.e. differentiation of leaf primordial in the apical growing region and genotypic variation and environmental effects as influenced for its expression. These findings are similar to that Mahanta and Paswan (2003) ${ }^{[10]}$ and Nanjan (1994) ${ }^{[12]}$.

Table 2: Plant height $(\mathrm{cm})$ and number of leaves per plant of gerbera cultivars as influenced by silicic acid levels

\begin{tabular}{|c|c|c|c|c|c|c|c|c|}
\hline \multirow{3}{*}{ Gerbera cultivars $(\mathrm{C})$} & \multirow{2}{*}{\multicolumn{3}{|c|}{$\begin{array}{l}\text { Plant height }(\mathrm{cm}) \text { after } 4^{\text {th }} \text { spray } \\
\text { Silicic acid levels }(\mathrm{ml} / \mathrm{L} \text { of water) }\end{array}$}} & \multirow{3}{*}{ Mean ' $C$ ' } & \multirow{2}{*}{\multicolumn{3}{|c|}{$\begin{array}{c}\text { No of leaves per plant } \\
\text { Silicic acid levels (ml/L of water) }\end{array}$}} & \multirow{3}{*}{ Mean ' $C$ ' } \\
\hline & & & & & & & & \\
\hline & $0 \mathrm{ml}$ & $2 \mathrm{ml}$ & $4 \mathrm{ml}$ & & $0 \mathrm{ml}$ & $2 \mathrm{ml}$ & $4 \mathrm{ml}$ & \\
\hline C1 -Rionegro & 34.03 & 41.41 & 39.85 & 38.43 & 31.66 & 32.33 & 32.00 & 32.00 \\
\hline $\mathrm{C} 2-$ Nijela & 33.53 & 40.63 & 39.73 & 37.96 & 29.00 & 32.66 & 31.66 & 31.11 \\
\hline C3 -Marinilla & 33.83 & 41.86 & 41.63 & 39.11 & 29.00 & 32.00 & 33.00 & 31.00 \\
\hline C4 - Natasha & 34.33 & 41.30 & 41.20 & 38.94 & 28.00 & 28.33 & 28.33 & 28.22 \\
\hline C5 - Vilassar & 33.25 & 38.17 & 38.26 & 36.56 & 27.33 & 29.00 & 31.00 & 29.11 \\
\hline C6-Amlet & 34.50 & 39.90 & 41.20 & 38.53 & 27.66 & 33.00 & 30.00 & 30.22 \\
\hline C7-Amelie & 34.20 & 40.06 & 40.00 & 38.08 & 23.00 & 27.00 & 28.33 & 26.11 \\
\hline Mean 'S' & 33.95 & 40.47 & 40.26 & & 27.38 & 31.04 & 30.61 & \\
\hline $\begin{array}{c}\operatorname{S.Em}( \pm) \\
\text { C D at } 1 \%\end{array}$ & $\begin{array}{c}\text { Factor C } \\
0.499 \\
1.428\end{array}$ & \multicolumn{2}{|c|}{$\begin{array}{c}\text { Factor } \mathrm{S} \\
0.326 \\
0.935\end{array}$} & $\begin{array}{c}\text { Factor } C^{*} \mathrm{~S} \\
0.864 \\
\mathrm{NS}\end{array}$ & $\begin{array}{r}\text { Factor } \\
1.041 \\
2.983\end{array}$ & \multicolumn{2}{|c|}{$\begin{array}{c}\text { Factor } \mathrm{S} \\
0.682 \\
1.953\end{array}$} & $\begin{array}{c}\text { Factor } C^{*} \mathrm{~S} \\
1.804 \\
\mathrm{NS}\end{array}$ \\
\hline
\end{tabular}




\section{Yield parameters}

\section{Number of flowers and Flower diameter}

Number of flowers produced varied significantly among cultivars of gerbera. However, higher numbers of flowers were produced in cultivar 'Marinilla' (15.11) and lower in cultivar 'Vilassar' (13.11). Number of flowers produced per plant, differed significantly with silicic acid levels. The application of silicic acid levels with $2 \mathrm{ml} / \mathrm{L}$ of water recorded higher flowers (14.76) than $0 \mathrm{ml} / \mathrm{L}$ of water (13.14) (Table 3). Interaction effect of cultivars and silicic acid levels on number of flowers did not differ significantly. Flower diameter varied significantly among cultivars of gerbera. Flower diameter was significantly higher with cultivars 'Vilassar' and 'Amelie' $(11.88 \mathrm{~cm})$ and was on par with all other cultivars of gerbera (Table 3). Flower diameter differed significantly with silicic acid levels. The flower diameter was significantly higher with application of silicic acid levels with $2 \mathrm{ml} / \mathrm{L}$ of water $(11.51 \mathrm{~cm})$ than $0 \mathrm{ml} / \mathrm{L}$ of water $(10.91 \mathrm{~cm})$ but was on par with $4 \mathrm{ml} / \mathrm{L}$ of water $(11.48 \mathrm{~cm})$. Interaction effect of cultivars and silicic acid levels on flower diameter did not vary significantly. These results were also in agreement with those obtained by Rani and Narayanan (1994) ${ }^{[14]}$ who stated that, silicon supply might have been improved the photosynthetic activity which enable rice plant to accumulate sufficient photosynthates and this helped in increased dry matter production and these together with efficient translocation resulted in more number of filled grains with increased test weight and ultimately led to higher grain and straw yield.

Table 3: Number of flowers and flower diameter $(\mathrm{cm})$ of gerbera cultivars as influenced by silicic acid levels

\begin{tabular}{|c|c|c|c|c|c|c|c|c|}
\hline \multirow{3}{*}{ Gerbera cultivars $(\mathrm{C})$} & \multirow{2}{*}{\multicolumn{3}{|c|}{$\begin{array}{c}\text { Number of flowers } \\
\text { Silicic acid }(\mathrm{ml} / \mathrm{L} \text { of water) -'S'}\end{array}$}} & \multirow{3}{*}{ Mean 'C' } & \multirow{2}{*}{\multicolumn{3}{|c|}{$\begin{array}{c}\text { Flower diameter }(\mathrm{cm}) \\
\text { Silicic acid }(\mathrm{ml} / \mathrm{L} \text { of water) -' } \mathrm{S}\end{array}$}} & \multirow{3}{*}{ Mean ' $C$ ' } \\
\hline & & & & & & & & \\
\hline & $0 \mathrm{ml}$ & $2 \mathrm{ml}$ & $4 \mathrm{ml}$ & & $0 \mathrm{ml}$ & $2 \mathrm{ml}$ & $4 \mathrm{ml}$ & \\
\hline C1-Rionegro & 13.33 & 14.66 & 14.66 & 14.22 & 10.00 & 11.27 & 11.43 & 10.90 \\
\hline $\mathrm{C} 2$-Nijela & 13.66 & 15.66 & 14.00 & 14.44 & 10.43 & 10.96 & 11.26 & 10.88 \\
\hline C3-Marinilla & 13.66 & 15.66 & 16.00 & 15.11 & 11.33 & 11.96 & 11.41 & 11.57 \\
\hline C4 - Natasha & 13.33 & 14.66 & 14.00 & 14.00 & 10.00 & 11.03 & 10.40 & 10.47 \\
\hline C5 - Vilassar & 12.00 & 14.00 & 13.33 & 13.11 & 11.80 & 11.70 & 12.16 & 11.88 \\
\hline C6-Amlet & 12.33 & 14.33 & 15.66 & 14.11 & 11.30 & 11.56 & 11.66 & 11.51 \\
\hline C7 - Amelie & 13.66 & 14.33 & 14.00 & 14.00 & 11.53 & 12.10 & 12.03 & 11.88 \\
\hline Mean 'S' & 13.14 & 14.76 & 14.52 & & 10.91 & 11.51 & 11.48 & \\
\hline $\begin{array}{l}\operatorname{S.Em}( \pm) \\
\text { C D at } 1 \%\end{array}$ & $\begin{array}{c}\text { Factor C } \\
0.514 \\
\text { NS }\end{array}$ & $\begin{array}{r}\mathrm{Fac} \\
0 . \\
0 .\end{array}$ & & $\begin{array}{c}\text { Factor } C * S \\
0.891 \\
\text { NS }\end{array}$ & $\begin{array}{r}\text { Fac } \\
0 . \\
0 .\end{array}$ & & & $\begin{array}{c}\text { Factor C*S } \\
0.293 \\
\text { NS }\end{array}$ \\
\hline
\end{tabular}

Stalk length: After 4th spray, silicic acid application as foliar spray with $2 \mathrm{ml} / \mathrm{L}$ of water level recorded significantly higher stalk length $(67.90 \mathrm{~cm})$ than $0 \mathrm{ml} / \mathrm{L}$ of water $(64.66 \mathrm{~cm})$ but it was on par with $4 \mathrm{ml} / \mathrm{L}$ of water $(67.29 \mathrm{~cm})$ (Table 4$)$. Stalk lengths were not influenced significantly by interaction effect of cultivars and silicic acid levels at all growth stages. Silicon application had beneficial effects on stalk length with increase in Si deposition, causing reduction in lodging and providing mechanical strength to stalk. These results were similar to several treatments studied, which increased $\mathrm{Si}$ tissue concentrations and peduncle thickening, but only the sodium silicate foliar sprays applied at 50 and $100 \mathrm{mg} / \mathrm{L} \mathrm{Si} \mathrm{showed}$ an increased peduncle height and flower diameter. These improved flower quality traits may be a result of an antitranspirant effect created by the foliar deposition of $\mathrm{Si}$ (Gillman and Zlesak, 2000) ${ }^{[3]}$.

\section{Vase life of flower}

Observations on vase life of flower did not differed significantly among cultivars of gerbera at different stages. Vase life of flower differed significantly with silicic acid levels. Application of silicic acid levels with $2 \mathrm{ml} / \mathrm{L}$ of water produced significantly higher vase life (14.33 days) over 0 $\mathrm{ml} / \mathrm{L}$ of water (12.76 days), but $2 \mathrm{ml} / \mathrm{L}$ was on par with 4 $\mathrm{ml} / \mathrm{L}$ of water (13.85 days) (Table 4$)$. Interaction effect of cultivars and silicic acid levels on vase life of flower did not vary significantly. These results obtained are in agreement with those obtained by Hodson and Sangster (1988) ${ }^{[5]}$ where accumulated monosilicic acid polymerizes into polysilicic acid and then transforms to amorphous silica, which forms a thickened silicone-cellulose membrane, by this means, a double cuticular layer protects plants.

Table 4: Stalk length $(\mathrm{cm})$ of gerbera cultivars at different growth stages as influenced by silicic acid levels

\begin{tabular}{|c|c|c|c|c|c|c|c|c|}
\hline \multirow{3}{*}{ Gerbera cultivars $(\mathbf{C})$} & \multicolumn{4}{|c|}{ Stalk length $(\mathrm{cm})$ after $4^{\text {th }}$ spray } & \multicolumn{4}{|c|}{ Vase life of flower (days) } \\
\hline & \multicolumn{4}{|c|}{ Silicic acid levels (ml/L of water) -'S' } & \multicolumn{4}{|c|}{ Silicic acid levels (ml/L of water)- ' $\mathrm{S}$ ' } \\
\hline & $\mathbf{0 ~ m l}$ & $2 \mathrm{ml}$ & $4 \mathrm{ml}$ & Mean 'C' & $\mathbf{0 ~ m l}$ & $2 \mathrm{ml}$ & $4 \mathrm{ml}$ & 13.77 \\
\hline C1 Rionegro & 67.06 & 70.36 & 70.66 & 69.36 & 12.66 & 14.33 & 14.33 & 13.55 \\
\hline C2 Nijela & 61.90 & 65.36 & 65.23 & 64.16 & 12.66 & 14.33 & 13.66 & 13.33 \\
\hline C3 Marinilla & 68.60 & 71.50 & 70.40 & 70.16 & 13.33 & 14.66 & 12.00 & 13.66 \\
\hline C4 Natasha & 64.76 & 66.06 & 66.00 & 65.61 & 13.33 & 13.33 & 14.33 & 13.88 \\
\hline C5 Vilassar & 61.93 & 66.26 & 65.40 & 64.53 & 12.00 & 14.33 & 15.33 & 13.88 \\
\hline C6 Amlet & 64.46 & 68.03 & 67.56 & 66.68 & 13.00 & 14.33 & 14.33 & 13.44 \\
\hline C7 Amelie & 63.90 & 67.73 & 65.80 & 65.81 & 12.33 & 15.00 & 13.00 & \\
\hline Mean 'S' & 64.66 & 67.90 & 67.29 & & 12.76 & 14.33 & 13.85 & \\
\hline $\begin{array}{c}\operatorname{S.Em}( \pm) \\
\text { C D at } 1 \%\end{array}$ & \multicolumn{2}{|c|}{$\begin{array}{c}\text { Factor C } \\
0.930 \\
2.665\end{array}$} & $\begin{array}{c}\text { Factor } \mathrm{S} \\
0.609 \\
1.745\end{array}$ & $\begin{array}{c}\text { Factor } \mathrm{C} * \mathrm{~S} \\
1.612 \\
\mathrm{NS}\end{array}$ & \multicolumn{2}{|c|}{$\begin{array}{c}\text { Factor C } \\
0.560 \\
\text { NS }\end{array}$} & $\begin{array}{c}\text { Factor } \mathrm{S} \\
0.367 \\
1.507\end{array}$ & $\begin{array}{c}\text { Factor } \mathrm{C} * \mathrm{~S} \\
0.970 \\
\text { NS }\end{array}$ \\
\hline
\end{tabular}




\section{Leaf silicon content}

Leaf silicon content varied significantly among cultivars of gerbera. Leaf silicon content was significantly higher with cultivar 'Amlet' $(0.129 \%)$ over 'Vilassar' $(0.090 \%)$, but was on par over other cultivars of gerbera. Silicon concentration of leaf tissue differed significantly with silicic acid levels. The foliar spray of silicic acid levels with $4 \mathrm{ml} / \mathrm{L}$ of water recorded significantly higher silicon concentration $(0.168 \%)$ than $0 \mathrm{ml} / \mathrm{L}$ of water $(0.022 \%$ ) (Table 5$)$. Higher levels of foliar silicon application increased the silicon content in leaf tissues. Since silicon is directly applied through foliar spray, there was no provision for any losses and silicon helped in more uptakes by reducing leaching losses. Kamenidou et al., (2008) ${ }^{[6]}$, observed the similar results. The results were in conformity with the findings of Baker et al., (2012) ${ }^{[1]}$ and Kamenidou et al. (2008) ${ }^{[6]}$. Silicon helped in more uptake of potassium. Baker et al., (2012) ${ }^{[1]}$ noticed that Kamenidou et al., (2009) ${ }^{[7]}$ and Kamenidou et al., (2008) ${ }^{[6]}$, also observed the application of potassium silicate $\left(\mathrm{K}_{2} \mathrm{SiO}_{3}\right)$ increases percent $\mathrm{K}$ in leaf and the similar results.

Table 5: Silicon content ( $\mathrm{Si}$ ) of leaf tissues as influenced by gerbera cultivars and silicic acid levels

\begin{tabular}{|c|c|c|c|c|}
\hline \multirow{3}{*}{ Gerbera cultivars $(\mathrm{C})$} & \multirow{2}{*}{\multicolumn{3}{|c|}{$\begin{array}{c}\text { Silicon content in leaf tissue (Si \%) } \\
\text { Silicic acid levels (ml/L of water)-'S' }\end{array}$}} & \multirow{3}{*}{ Mean ' $C$ ' } \\
\hline & & & & \\
\hline & $0 \mathrm{ml}$ & $2 \mathrm{ml}$ & $4 \mathrm{ml}$ & \\
\hline C1 - Rionegro & 0.033 & 0.173 & 0.173 & 0.127 \\
\hline $\mathrm{C} 2-$ Nijela & 0.013 & 0.143 & 0.170 & 0.109 \\
\hline C3 - Marinilla & 0.017 & 0.153 & 0.163 & 0.111 \\
\hline C4 - Natasha & 0.023 & 0.157 & 0.150 & 0.110 \\
\hline C5 - Vilassar & 0.013 & 0.117 & 0.140 & 0.090 \\
\hline C6-Amlet & 0.033 & 0.167 & 0.187 & 0.129 \\
\hline C7-Amelie & 0.020 & 0.153 & 0.193 & 0.122 \\
\hline Mean 'S' & 0.022 & 0.152 & 0.168 & \\
\hline $\begin{array}{l}\operatorname{S.Em}( \pm) \\
\text { C D at } 1 \%\end{array}$ & $\begin{array}{c}\text { Factor C } \\
0.009 \\
0.025\end{array}$ & $\begin{array}{c}\text { Factor } \mathrm{S} \\
0.006 \\
0.016\end{array}$ & & \\
\hline
\end{tabular}

\section{Conclusion}

The results of the investigation showed that among cultivars 'Marinilla' showed superior results with respect to number of flowers, stalk length and plant height. Foliar spray of silicon in the form silicic acid at $4 \mathrm{ml} / \mathrm{L}$ of water increased plant height. Silicic acid spray at $2 \mathrm{ml} / \mathrm{L}$ of water showed better results with respect to number of flowers, flower diameter, stalk length and vase life of flower. Therefore, application of silicic acid at $2 \mathrm{ml} / \mathrm{L}$ of water is an effective way of increasing production of gerbera in protected conditions.

\section{Acknowledgement}

The study was conducted in protected condition at University of Horticultural Sciences, Bagalkote. I am grateful for their help during the conduct of the experiment.

\section{References}

1. Baker ANH, Abd-Eladl M, Eid TA. Silicon and water regime responses in bean production under soil saline condition. Journal of Applied Sciences Research 2012;8(12):5698-5707.

2. Chauhan N. Performance of Gerbera genotypes under protected cultivation. M.Sc. Thesis. Univ. Agric. Sci., Dharwad, Karnataka State, India 2005.

3. Gillman JH, Zlesak DC. Mist Applications of Sodium Silicate to Rose (Rosa L. × Nearly Wild') Cuttings Decrease Leaflet Drop and Increase Rooting. Hort Science 2000;3(4):773-773.

4. Gunnarson I, Arnorsson S. Amorphous silica solubility and the thermodynamic properties of $\mathrm{H}_{4} \mathrm{SiO}_{4}$ degrees in the range of 0 degrees to 350 degrees $\mathrm{C}$ at $\mathrm{P}_{\text {sat. }}$ Geochimica et Cosmochimica Acta 2000;64:2295-307.

5. Hodson MJ, Sangster AG. Silica deposition in the inflorescence bracts of wheat (Triticum aestivum). Scanning electron microscopy and light microscopy. Caanada. J Bot 1988;66:281-287.
6. Kamenidou S, Cavins TJ. Silicon supplements affect horticultural traits of greenhouse-produced ornamental sunflowers. Hort. Sci 2008;43(1):236-239.

7. Kamenidou S, Cavins TJ, Marek S. Evaluation of silicon as a nutritional supplement for greenhouse zinnia production. Scientia Horticulturae 2009;119(3):297-301.

8. Lindsay S ed. Light Metals 2011. Springer 2016.

9. Ma JF, Takahashi E. Soil, Fertilizer and Plant Silicon Research in Japan. Elsevier 2002.

10. Mahanta P, Paswan L. Assessment of comparative performance of some gerbera (Gerbera jamesonii Bolus) cultivars under open conditon and plastic rain shelter in Assam condtion. Proc. Indian Soc. Oranam. Hort 2003, 154-165.

11. Nagaraja MS, Srinivasamurthy CA. Soil fertility in physically degraded land: Are we over estimating? Current Sci 2009;99:1534-1535.

12. Nanjan K. Gerbera as a cut flower. (In: FloricultureTechnology, Trades and Trends (Ends) Prokash, J and Bhandry, K. R.) Oxford and IBH Publishing Co. Pvt. Ltd. Calcutta 1994, 70-75.

13. Narayanaswamy C, Prakash NB. Calibration and categorization of plant available silicon in rice soils of South India. Journal of Plant Nutrition 2009;32:12371254.

14. Rani AY, Narayan A. Role of silicon in plant growth. Agro. Ann. Rev. Plant Physiol. (B\&A) 1994;1:243-262.

15. Reddy SB, Nagaraja MS, Punit Raj TS, Dhumgond P, Vignesh NS. Soil humic and fulvic acid fractions under different land use systems. Madras Agric. J 2012;99:507510.

16. Richmond KE, Sussman M. Got silicon? The nonessential beneficial plant nutrient. Current Opinion in Plant Biology 2003;6:268-72. 